\title{
Permeability and Direct Shear Tests Characteristics of Railway Subballast
}

\author{
Guoqing Jing ${ }^{1}$, Zijie Wang ${ }^{1}$, Hongmei Huang ${ }^{1}$ and Yan Wang ${ }^{2, *}$ \\ ${ }^{I}$ School of Civil Engineering, Beijing Jiaotong University, Beijing 100044, P.R. China \\ ${ }^{2}$ School of Civil Engineering and Architecture, Zhejiang Sci-Tech University, Hangzhou, 310018, P.R. China
}

\begin{abstract}
Permeability, filtration and shearing strength were widely considered to be the key properties in evaluating the performance of railway subballast. An investigation on these key properties of railway subballast was presented in this paper. A constant head permeability test and a middle scale direct shear test of railway subballast were conducted in the research, aiming to investigate the subballast permeability and shear direct tests characteristics. Four different designed gradations within the standards were subjected to the investigation in order to study the particle size distribution effect on permeability performance of subballast. Lab results showed that drainage capacity and shearing strength of subballast highly correlated with each other. Subballast with more large-size particles and a low coefficient of uniformity were proved to acquire good drainage of water and strong resistance ability to shear.
\end{abstract}

Keywords: Drainage, particle size distribution, permeability test, subballast.

\section{INTRODUCTION}

Railway subballast which serves between ballast layer and subgrade layer is composed of much finer particles than the upper ballast. It was widely considered to work as a filter which on the one hand prevented the mutual penetration between ballast and soft soil subgrade (known as the slurry pumping), on the other hand permitted drainage of water from the above rainfall and wet subgrade below [1]. Any sand or gravel stones could serve as subballast provided that they meet the grading standard and, most importantly, filtering requirements. Meanwhile as an important load-bearing layer in the track structure, subballast needs adequate shearing strength to transmit and spread the cyclic load from to the soft soil subgrade as trains roll by.

A good drainage of ballasted bed is necessary to ensure an acceptable track performance. While as ballast ages, the track bed becomes slowly fouled by slurry from the soil subgrade, wearing between particles and fines like sand and coal ash from the surface ballast in some heavy-haul lines. For instance, cyclic loading from the passing traffic transferred to the subballast layer and enhanced the attribution and create fines at the particles interface [1]. The trapped fines in the void changed the porosity and grading of ballast and, as a result, reduced the drainage capability of subballast layer. According to Huang about $15 \%$ of the fouling source was the infiltration from subgrade and Selig regarded this percentage as $13 \%[1,2]$. In some poorly drained situation like some low lying coastal areas, cyclic rail load acted as a pump which generated a huge pore water pressure and thus applied a vertical seepage force which sucked the slurry into the ballast layer [3]. So drainage capability played a key role in stability and safety of the track structure.
Deep understanding of subballst function especially the mechanism of drainage when serving as a filtration is of vital importance to ensure a maximum performance of the subballast filter layer. While clogging of subballast and problems concerned were generally ignored during the design of the track. Previous design procedures for filters of granular material paid more attention to the soil erosion, stabilizing dams and retaining structures which differ from subballast in structure and function [4-8]. Although some researchers proposed amount of empirical models regarding to the filtration of granular materials for the embankment dams [9-13], few of them was fit for ballasted track construction as the loading system of the railway track was cyclic different from the slowly penetration force of embanks. According to Trani, cyclic loading generated by the passing trains has a great influence on the seepage of the filtration of the subballast layer [14]. The subballast layer was subjected to a load of $30 \mathrm{kPa}$ at least and $70 \mathrm{kPa}$ at most which equals to the vertical stress induced by heavy haul trains, according to Christie [15]. Trani considered plastic deformation and accumulation of the migration fine created during the cyclic load as the main factors that contribute to the reduction of the porosity and permeability over time [16]. Therefore, research on the filtration performance of subballast was required to establish a design criteria for the railway system. To solve the problems above, many other researchers even devoted in exploring possibilities of using bituminous subballast layers instead of granular ones [17-20]. However this kind of theoretical method is far from application and much expensive for large-scale applications.

To satisfy the drainage requirement of subballast, uniformly graded particles were usually applied in the construction, which may lead to a structurally instability and poor filtration due to the large void between particles. From the perspective of the structure itself, demand of the main functions of subballast are contradictory to some extent. So a 
balanced grading is needed to ensure the filtration, drainage as well as enough shearing strength to reduce track pumping and ballast fouling and prolong track lifetime.

Abundant researches were conducted to better particles composition [21-24]. Results revealed that particle size distribution have a deep influence on the subballast performance which showed well-graded packs of ballast which have a high $\mathrm{Cu}$ usually have two problems which were size segregation and reduction of drainage [25]. Research by Jannati also proved that a higher $\mathrm{Cu}$ often causes a higher rate of breakage [19], while lab results showed that well-graded subballast had enhanced filtration ability. For the uniformly graded ballast which have a low $\mathrm{Cu}$, researches were conducted to show that it have a poor resistance against deformation and its advantage of permeability would be weakened sharply after the application of cyclic stress.

In this paper four gradations of subballast were chosen according to Chinese high speed railway standard to explore the effect of aggregate gradation on the two structural contradictory properties, permeability and shearing strength of the subballast, through constant head permeation experiment and direct shear experiment. Results revealed that particle size distribution have a deep influence on the performance of subballast and specimen with more fine particles showed good filtration while poor permeability and shearing strength. Gradations of subballast have a deep impact on the shearing strength and the permeability which demonstrate that voids between particles played a key role on the performance of subballast. The resistance of the subballast layer decreased as the percentages of fine particles increased which retained more water which filled the voids in the same situation. Meanwhile the permeability also decreased as the voids were filled with more fine particles. Therefore, permeability and resistance were correlated and both have a strong relation with particle size distribution.

\section{MATERIAL AND EXPERIMENTAL METHODOL- OGY}

This section includes descriptions of properties of subballast with different gradations applied in this research. Setups and procedures of the constant head permeability test and direct shear test were also introduced in this part. The hydraulic conductivity was determined through the permeability and then the same sample with the same gradations were used in the following direct shear test.

\subsection{Material}

The rail road subballast which meet Chinese railway standard were supplied by CARS and involved materials with particles ranging from 0.075 to $45 \mathrm{~mm}$. As gradations deeply influence performance of particles, the selection of gradation has a great effect on the results of the test and research. Four gradations of subballast were designed according to the standard to ensure sufficient void which could provide efficient drainage of water.

After carefully sieving the granular material into four ranges of size by conducting sieve analysis test in Beijing Jiao tong University, the particle size distributions of the four samples were plotted in Fig. (1) and thus the following parameters were determined and shown in Table 1: maximum size, minimum size, coefficient of uniformity $(\mathrm{Cu})$ and coefficient of curvature $(\mathrm{Cc})$.

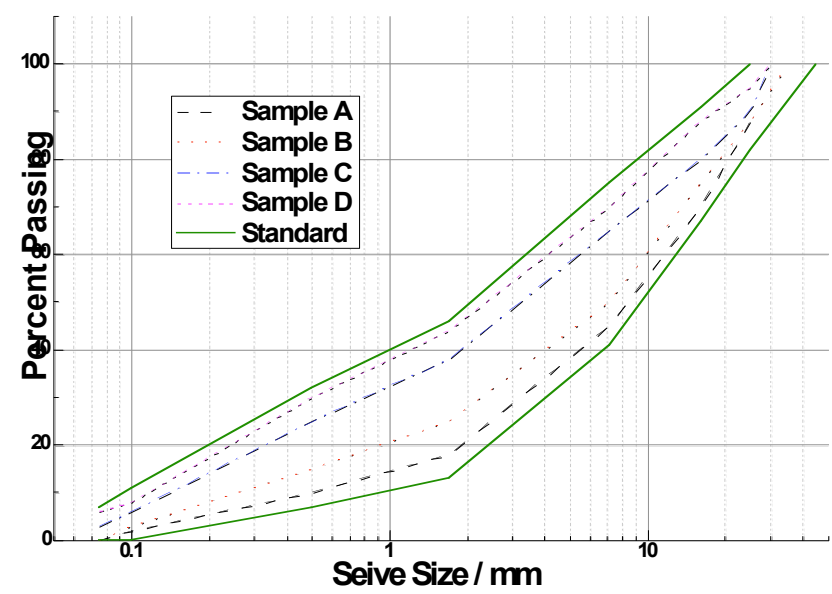

Fig. (1). Particle size distribution.

\subsection{Permeability Test}

A middle-scale permeameter which could accommodate a specimen of $40 \mathrm{~mm}$ in diameter and $40 \mathrm{~mm}$ in height was introduced in the test. It was made of transparent plastic to allow visual observation and the constant head was put above the apparatus with a $5 \mathrm{~cm}$ diameter pipe installed below the fiber screen which was used to drain the water in the cell. In order to prevent the fines going through, a fiber glass layer was laid beneath the sample. The principle of constant head permeameter which was shown as Fig. (2) was designed and assembled in Hydraulic Engineering Laboratory in Shangdong University.

In order to accurately record the pressure and water velocity during the test, two electrical water pressure sensors and an ultrasonic velocity meter were introduced in the test. All sensors were connected to the computer through an A/D converter and a computer program was written before the test to control the process of the test and record the data in

Table 1. Parameters of four kinds of specimen.

\begin{tabular}{|c|c|c|c|c|}
\hline Sample & A & B & C & 30 \\
\hline \hline maximum size & 45 & 35 & 0.075 & 25 \\
\hline minimum size & 0.5 & 0.1 & 32 & 0.03 \\
\hline $\mathrm{Cu}$ & 14 & 27 & 0.83 & 0.57 \\
\hline $\mathrm{Cc}$ & 1.79 & 1.55 & \\
\hline
\end{tabular}


real-time. Before the permeability test each sample was immersed into the water for more than one day to completely fill the micro pours on the surface of subballast.

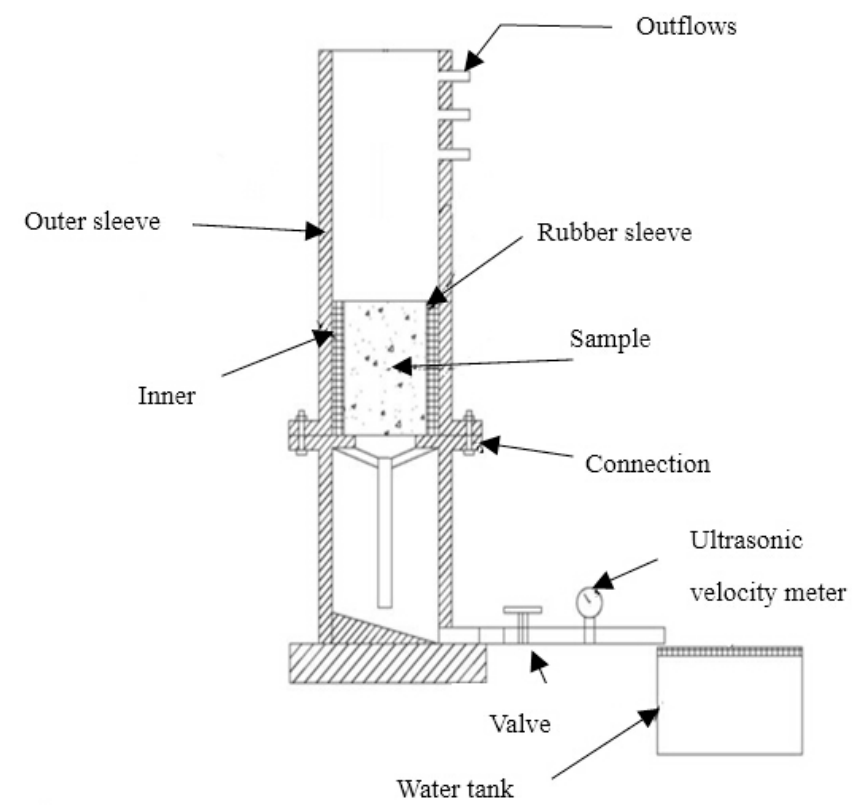

Fig. (2). Principle of apparatus of permeability test.

The cylindrical test cell as well as the fiber screen above which the packed subballast was put should be washed before every test. To get accurate results, the fiber screen should be fastened tight in the bottom and around the corner of the cell to prevent the migrating of fine particles. A steady state flow was established as water gradually filled the transparent test cell to ensure the applicable of Darcy law as follows:

$k=\frac{v}{i}=\frac{v L}{\Delta h}$

where $\mathrm{k}$ is the permeability; $\mathrm{v}$ is the velocity of water in specimens; $i$ is the hydraulic gradient; $\triangle \mathrm{h}$ is the head loss; $\mathrm{L}$ is the length of the specimen.

Firstly, water drained out from the bottom pipe was collected for a recorded time period. Then this procedure should be repeated twice or more for each grading of subballast sample to get mean required values above. Finally, the permeability of each sample could be calculated through the formula above.

\subsection{Direct Shear Test}

Direct shear test on subballast was then performed in railway engineering laboratory of Beijing Jiaotong University. The specimens used in this test had the same grading with those used in the permeability test in order to investigate the influence of size effect and three serials of test were conducted for each gradation under the same condition. Since aggregates studied in this test is small $(45 \mathrm{~mm}$ top sized subballast sample), the middle-scale direct shear apparatus used in this test with a size of $30 * 36 * 24 \mathrm{~cm}$ could minimize the size effect.
The middle-scale direct shear apparatus shown in Fig. (3) has an upper and a lower shear box. Afterwards the subballast were packed by lift in the shear box where each lift should be compacted with a vibratory, a certain normal stress was applied to the subballast sample. With the lasting vertical pressure, the sample was sheared strain-controlled with a loading rate of $5 \mathrm{~mm} / \mathrm{min}$ by pushing the upper shear box horizontally during which the lateral displacement and the shearing force were recorded through the sensor installed on the inner surface of the box. For safety reasons, the maximum horizontal displacement was set to $10 \%$ strain which equals to $3 \mathrm{~cm}$ in total.

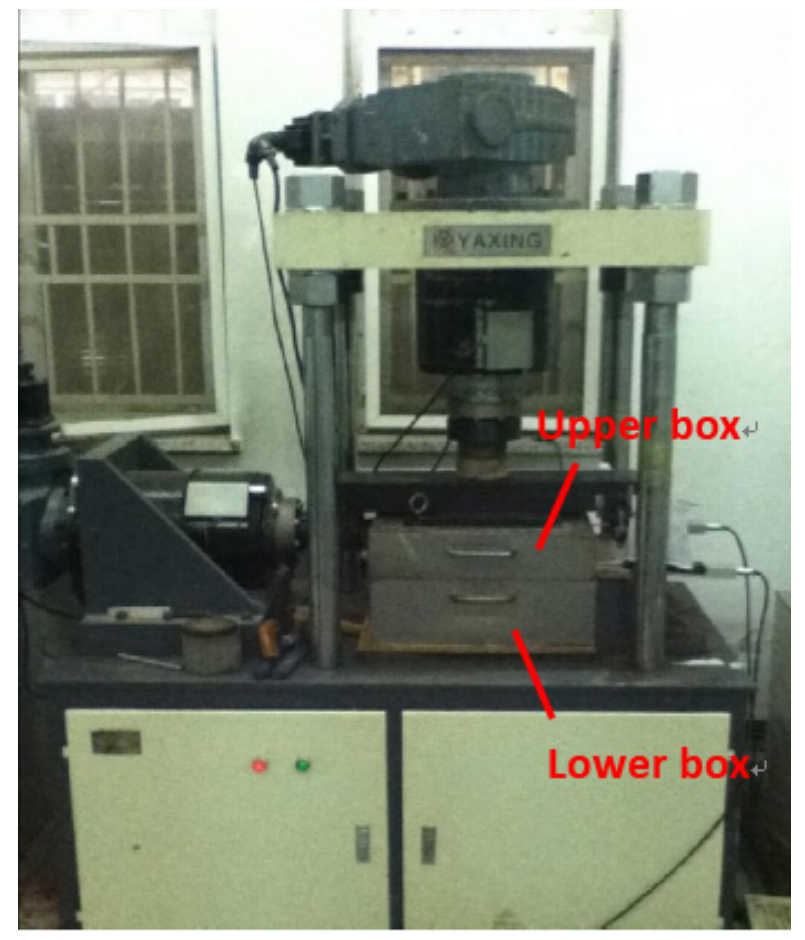

Fig. (3). Direct shear apparatus.

\section{RESULTS AND DISCUSSIONS}

Several constant head permeability tests were conducted for each grading after which the calculated hydraulic conductivities of the four kinds of subballast with equation (1) were plotted in Fig. (4) and indicated by different shapes and colors of points and lines. An obvious increase of the conductivity could be founded as the size of the particle became larger from sample D to A which may due to the increasing of the void between aggregates since the grading curve of the samples moved rightwards. While from this figure it could be shown that the size effect of particles became deeper when the dimension turned to be small enough. The value of permeability for sample A B C lies above the $10^{-5} \mathrm{~m} / \mathrm{s}$ threshold. Lambe and Head indicated that these three kinds of gradations possess good drainage while sample D should only be classified as relative poor drainage which may due to the increasing percentage of fine particles in sample D [26, 27]. Size distribution played a major role in the permeability of subballast. The research results indicate that the subballast material should be well specified for the PSD, aiming the good performance of water permeability, as well as the compression strength ability. 


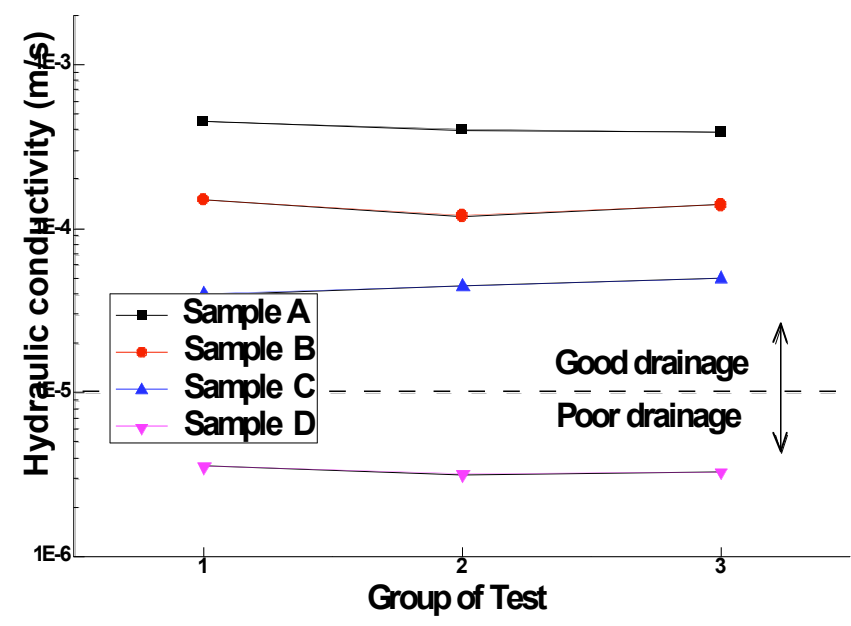

Fig. (4). Permeability of subballast.

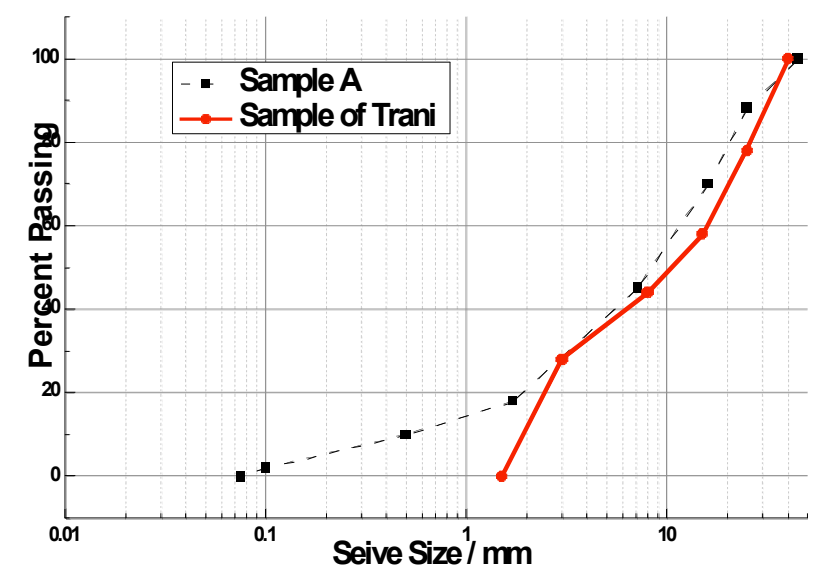

Fig. (5). Comparison of particle size distribution.

Trani also conducted a permeability experiment with railway subballast which conforms to standard of Australia. The particle size distribution of specimen he used in the test is shown as the thicker line in Fig. (5). It can be concluded from the comparison of these two distributions that two samples were quite familiar, while sample A contained more fine particles than sample used by Trani. Thus a relative big distinction in the permeability of the two samples could be found in the experiment results through Fig. (6). Sample A showed an obvious reduction of drainage capability in the test which may due to the presence of the particles with a smaller size. These demonstrate that small-sized particle played a key role in governing the permeability of subballast. The accumulated fine particles generated from the abrasion between particles and pollution greatly influenced the performance of subballast and ballast.

To investigate the influence of the confining pressure, the direct shear test was conducted for different samples of subballast at four different normal pressures, $50 \mathrm{kpa}, 100 \mathrm{kpa}$, $150 \mathrm{kpa}, 200 \mathrm{kpa}$. Fig. (7) which reveals the behavior of each sample shows the typical trend of the shear stress varying with the lateral displacement of the shear box under the four normal stresses for sample A to D. The curves plotted in this figure are not smooth which may due to the crushing of the particles during the shearing process and this crushing which

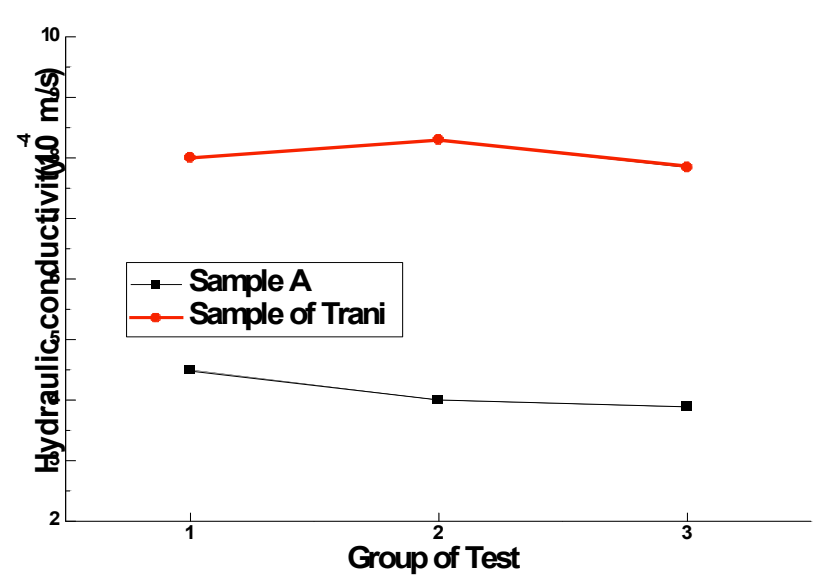

Fig. (6). Comparison of permeability of subballast.

was reflected as a sudden falling in the curve could be observed visually in the shearing box after the test.

The shear force dramatically increased in the beginning of shear displacement until the sample researched its shearing strength which also improved as the normal strength increased. For the test with large normal stress (150kpa, $200 \mathrm{kpa}$ ) the shear stress slightly reduced after $1 \mathrm{~cm}$ of the shearing displacement.

Meanwhile for the tests with relative low normal stress which agreed with the actual situation, the shearing stress versus the shear displacement of different gradations was plotted in Fig. (8) which showed that samples with higher $\mathrm{Cu}$ while lower Cc showed stronger resistance to shearing. This may mainly due to the presence of larger amount of largesized particles which caused higher overall density and average stiffness of the sample. Results showed that there was no significant gap between peak shear stresses of sample A to $\mathrm{C}$, while the shearing strength of sample D was much lower than other samples with higher $\mathrm{Cu}$. What's more, samples with more fine particles and higher $\mathrm{Cu}$ reached its shearing strength earlier than the others. On the other hand, the dilatancy effect was observed during the lab test except for small-sized sample D which exhibited a constant contraction process all along.

\section{CONCLUSION}

The railway subballast constant head permeability test and direct shear tests of railway subballast were employed to investigate the possible relation between permeability and shearing strength which both were the key properties for subballast. During the laboratory test, four designed gradations were applied to the experimental materials according to Chinese railway standard. A steady state laminar flow was maintained to ensure the applicability of Darcy's law in the permeation experiment and four normal stresses ranging from $50 \mathrm{kpa}$ to $200 \mathrm{kpa}$ were applied in the shear test. These two lab test results suggested that grain compositions, to be more specific the particle size gradations, influenced the performance of subballast material. Some important conclusions are given as follows:

1. The two lab tests suggested that the permeability and shearing strength which are the two vital properties of subballast are correlated significantly. 


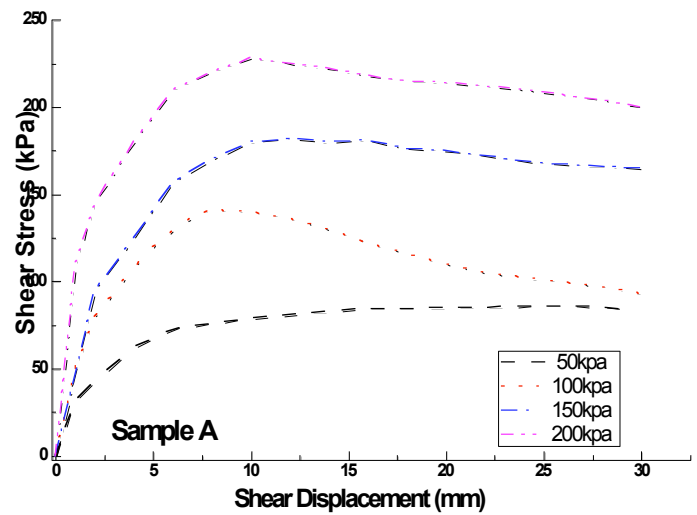

(7-1)

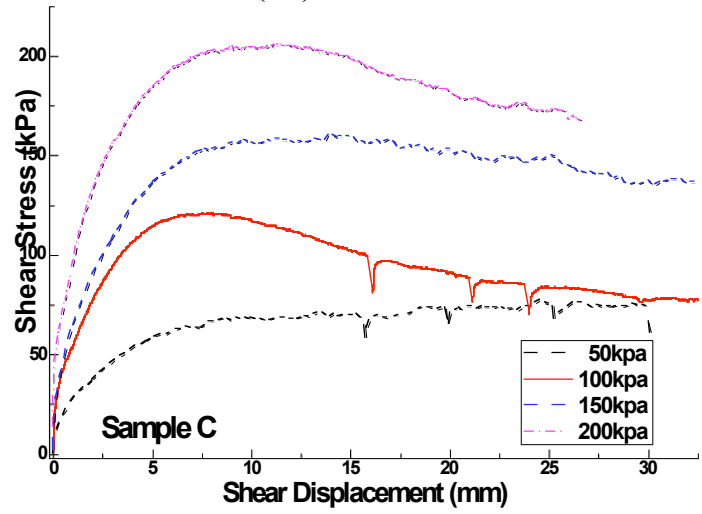

(7-3)

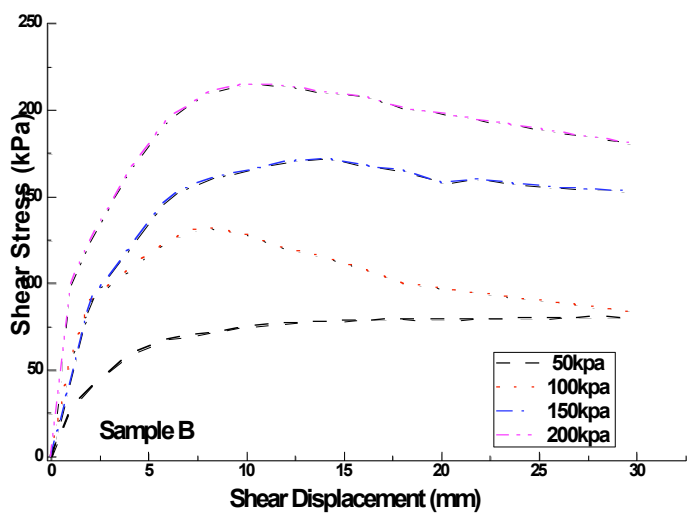

(7-2)

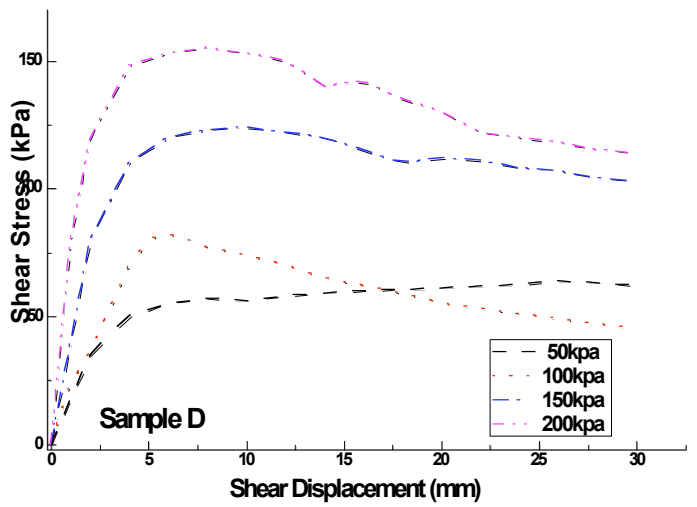

(7-4)

Fig. (7). Shear displacements vs. shear stress under different normal stress.
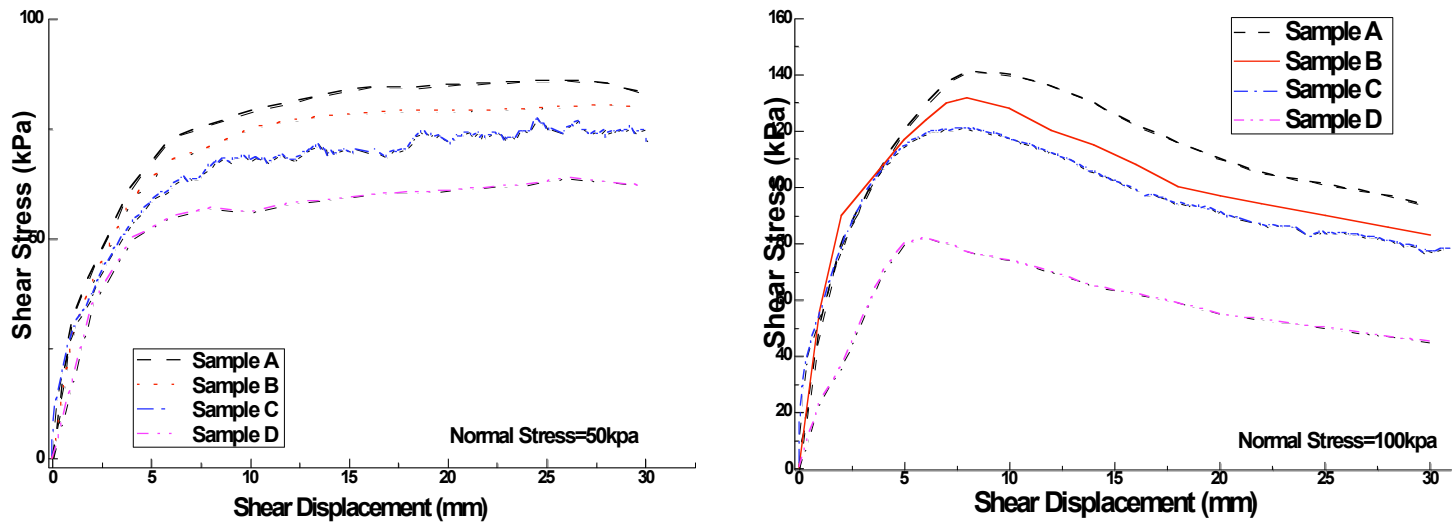

(8-1)

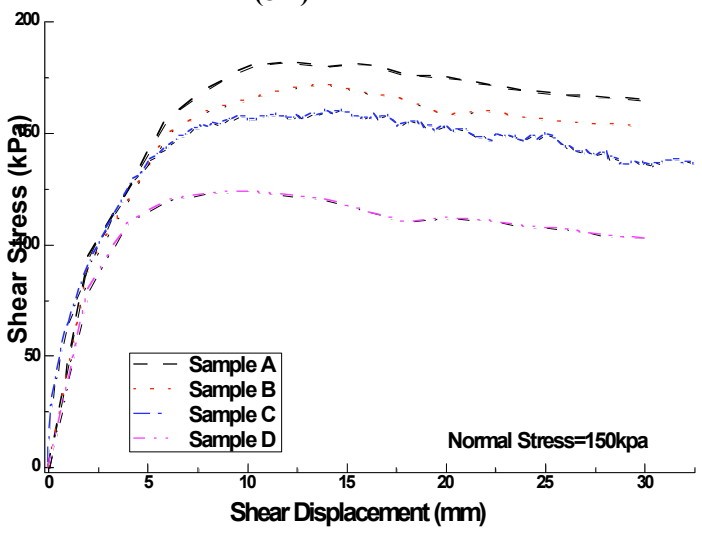

(8-3)

(8-2)

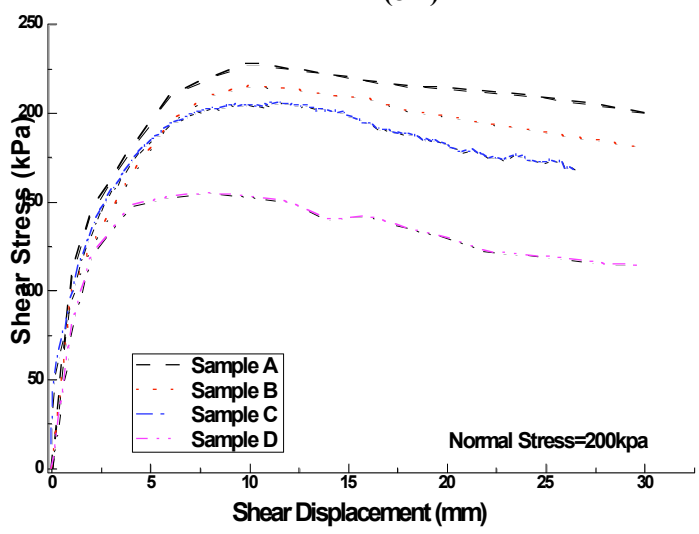

(8-4)

Fig. (8). Shear displacements vs. shear stress. 
2. Drainage ability is vulnerable impacted by subballast gradations, and the sample direct shear tests are less correlated by subballast gradations and particle grain composition.

3. Samples with more fine grain and a higher $\mathrm{Cu}$ showed relative poor resistance against the shearing deformation and drainage of water.

4. The influence of gradations of particles became larger when the average diameter turned smaller.

5. Particles with relative smaller size played a key role in governing the properties of subballast, especially the drainage capability.

6. Coarse-grained sample A showed a relative good drainage of water and high shearing strength, while considering the significant filtration property of subballast, grading of sample B is recommended in construction of railway lines.

However, in order to have a proper design for the layer of subballast, an effective gradation is correlated performance of both drainage and resistance of shear ability.

With an aim to microscopic understanding the interactions, an explicit time-integration scheme can be used to evaluate the coupled fluid-particle response. The flow domain is discretized into parallelepiped cells and averaged Navier-Stokes equations are solved using a finite volume technique. Basic permeability test microscopic simulations could be used to assess the capabilities of the DEM-CFD model. The simulations can be performed to investigate the range of validity of Darcy's law for water interactions with granular matter.

\section{CONFLICT OF INTEREST}

The authors confirm that this article content has no conflict of interest.

\section{ACKNOWLEDGEMENTS}

Research reported in this paper was supported by the Fundamental Research Funds for the Central Universities (2014JBM095).

\section{REFERENCES}

[1] E.T. Selig, J.M. Waters, Track Geotechnology and Substructure Management, Thomas Telford Ltd, London, 1994.

[2] H. Huang, E. Tutumluer, W. Dombrow, "Laboratory characterization of fouled railroad ballast behavior," Transportation Research Record: Journal of the Transportation Research Board, vol. 2117, pp. 93-101, 2009,

[3] I.M. Alobaidi, D.J. Hoare, "Mechanism of pumping at the subgrade-subbase interface of highway pavements," Geosynthetics International, vol. 6, pp. 241-259, 1999.

[4] G.R. Fischer, B.R. Christopher, R.D. Holtz, "Filter criteria based on pore size distribution," In: Proceedings of the $4^{\text {th }}$ International Conference on Geotextiles, The Hague, vol. 1, pp. 289-294, 1990.

[5] J. Sherard, L. Dunnigan, J. Talbot, "Basic properties of sand and gravel filters," Journal of Geotechnical Engineering, vol. 110, pp. 684-700, 1984.
[6] B. Indraratna, M. Locke, "Analytical modelling and experimental verification of granular filter behaviour," In: $3^{\text {rd }}$, International Conference on Geofilters; Filters and Drainage in Geotechnical and Environmental Engineering, pp. 3-26, 2000.

[7] J.M. Shilstone, "Concrete mixture optimization," Concrete International, vol. 12, no. 6, pp. 33-39, 1990.

[8] D.M. Roy, B.E. Scheetz, M. R. Silsbee, "Processing of optimized cements and concretes via particle packing," MRS Bulletin, vol. 18, pp. 45-49, 1993.

[9] B. Indraratna, F. Vafai, "Analytical model for particle migration within base soil-filter system," Journal of Geotechnical and Geoenvironmental Engineering, vol. 123, pp. 100-109, 1997.

[10] F. de Larrard, T. Sedran, "Optimization of ultra-high-performance concrete by the use of a packing model," Cement and Concrete Research, vol. 24, pp. 997-1009, 1994

[11] P. Goltermann, V. Johanson, L. Palbol, "Packing of aggregates: An alternative tool to determine the optimal aggregate mix," Material Journal, vol. 94, pp. 435-443, 1997.

[12] M. Locke, B. Indraratna, G. Adikari, "Time-dependent particle transport through granular filters," Journal of Geotechnical and Geoenvironmental Engineering, vol.127, pp. 521-528, 2001.

[13] B. Indraratna, A.K. Raut, "Enhanced criterion for base soil retention in embankment dam filters," Journal of Geotechnical and Geoenvironmental Engineering, vol.132, pp. 1621-1627, 2006.

[14] L.D. Trani, B. Indraratna, "An assessment of subballast filtration under cyclic loading," Journal of Geotechnical and Geoenvironmental Engineering, vol.136, pp, 1519-1528, 2010.

[15] D. Christie, Bulli, "Field trial: Vertical and lateral pressure measurement," Rail CRC Seminar, Australia, 2007.

[16] L.D. Trani, B. Trani, Indraratna, "A new method of filtration design on rail track subballast," Advances in Geotechnical Aspects of Roads and Railways, pp. 89-88, 2012.

[17] P.F. Teixeira, A.L. Pita, P.A. Ferreira, "New possibilities to reduce track costs on high-speed lines using a bituminous sub-ballast layer," International Journal of Pavement Engineering, vol.11, pp. 301-307, 2010

[18] B. Indraratna, H. Khabbaz, W. Salim, D. Christie, "Geotechnical properties of ballast and the role of geosynthetics in rail track stabilization," Journal of Ground Improvement, vol.10, pp, 91-102, 2006.

[19] R.J. Aghdam, A. Soroush, "Interpretation of stress-dependent mechanical behaviour of rockfill materials," In: Proceedings of the $18^{\text {th }}$ International Conference on Soil Mechanics and Geotechnical Engineering, Paris, September 2-6, pp. 353-356, 2013.

[20] T.M. Ferreira, "Influence of incorporating a bituminous sub-ballast layer on the deformations of railway trackbed," Dissertation for Integrated Master Degree in Civil Engineering. Instituto Superior Técnico - Technical University of Lisbon, Portugal, 2007.

[21] E. Tutumluer, H. Huang, Y.M.A. Hashash, J. Ghaboussi, "AREMA Gradations Affecting Ballast Performance Using Discrete Element Modeling (DEM) Approach," In: Proceedings of the AREMA 2009 Annual Conference \& Exposition, Chicago, IL - September 20-23, 2009

[22] T. Nakao, S. Fityus, "Direct shear testing of a marginal material using a large shear box," Geotechnical Testing Journal, vol. 31, pp. 393-403, 2008 .

[23] I. Alobaidi, D.J. Hoare, "Mechanisms of pumping at the subgradesubbase interface of highway pavements," Geosynthetics International, vol.6, pp. 241-259, 1999.

[24] B. Indraratna, S. Nimbalkar, D. Christie, C. Rujikiatkamjorn, J. Vinod, "Field assessment of the performance of a ballasted rail track with and without geosynthetics," Journal of Geotechnical and Geoenvironmental Engineering, vol. 136, pp. 907-917, 2010.

[25] B. Indraratna, F. Vafai, E. Dilema, "An experimental study of the filtration of a lateritic clay slurry by sand filters," In: Proceedings of the ICE - Geotechnical Engineering, April 1, vol. 119, no. 2, pages $75-83,1996$.

[26] T.W. Lambe, R.V. Whitman, Soil mechanics, John Wiley and Sons, Inc., USA, 1969.

[27] K.H. Head, Manual of Soil Laboratory Testing, Whittles Publishing, UK, 2006. 